"Globalisation: Trends and Issues for Government"

Michael Wild

CSGR Working Paper No. 54/00

May 2000
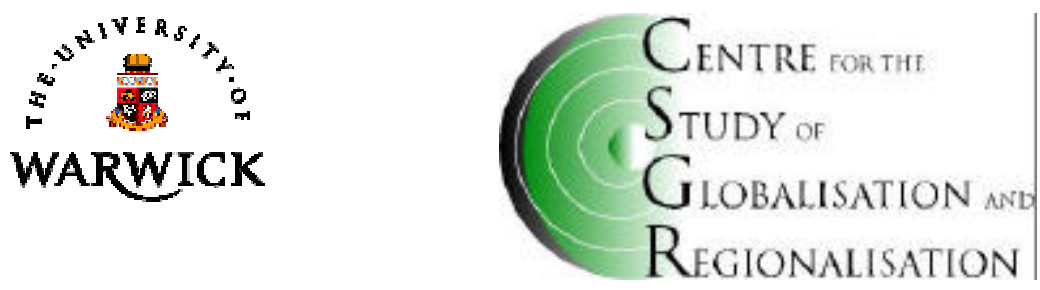


\title{
Globalisation: Trends and Issues for Government ${ }^{1}$
}

\author{
Michael Wild ${ }^{2}$
}

ICL and DTI Future Unit.

CSGR Working Paper No. 54/00

May 2000

\begin{abstract}
:
Globalisation has many faces, and they do not always align neatly with the organisation of government. For example, some aspects of globalisation - trade, foreign investment, merger policy - fall clearly within the remit of the UK Department of Trade \& Industry (DTI). But as well as these economic and commercial globalisations, Anthony Giddens and others have drawn attention to others - social, environmental, cultural, and political. These are interrelated in ways we do not yet understand, still less control - yet they have clear impact on policy areas which are of great interest to DTI. In particular, issues of ethics and sustainability, and the way in which they will interact with personal value systems, are probably the single largest imponderable for all parts of government over the next 20 years.

Multi-faceted, rapidly changing globalisation will profoundly affect the way corporations and other institutions operate. These changes will challenge the existing ways of government, extending into and beyond all areas of DTI's work. Government more than other actors has power to shape the future by arranging itself to deal with a range of possible futures; but incremental changes to structures designed for an earlier age may not achieve this. Scenario planning techniques make it possible to "think aloud" about the co-evolution of governmental institutions with the environment in which they operate, and open up the possibility of steering that process better by thinking about different possible futures. When other actors adopt new global ways to organise, co-ordinate, and achieve agility at scale, what should be the response of government?
\end{abstract}

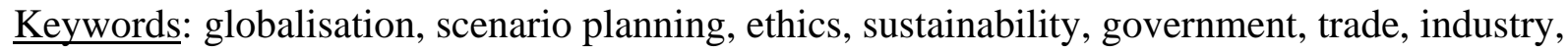
policy

Address for correspondence:

Michael Wild

Twin Oaks

Western Avenue

Woodley

Reading, RG5 3BH, UK

email: mwild@iee.org

\footnotetext{
${ }^{1}$ I am grateful for comments, criticisms, and ideas from many colleagues in DTI and ICL; in particular John Reynolds, Christopher Moir, David Coates, David Evans, George Hall, Gill Ringland, and Chris Yapp. This material was first prepared as a background paper supporting a presentation to members of DTI's Board. I am indebted to Richard Higgott for inviting me to present it to the CSGR and the Warwick MPA course, and for his subsequent suggestion that the presentation material be incorporated into the original paper for publication as a CSGR working paper. Responsibility for the analysis and conclusions remains, of course, mine alone.

${ }^{2}$ Michael Wild is a Managing Consultant in ICL's Business Analysis group. During 1999 he was seconded parttime to the DTI Future Unit.
} 


\section{Introduction}

In this paper we outline several aspects of globalisation, then look at some questions which these raise for DTI, and possible implications for the way in which it goes about its work. This paper is not then an in-depth analysis, but a wide-ranging summary of the present and a pointer to some important issues for the future.

The DTI Future Unit is committed to making as much of its work as possible readily available to those with an interest. In that spirit, this paper is offered as a contribution to public debate. It is important to understand, though, that it is not a statement of policy, nor is it setting out views for consultation.

\section{Aspects of Globalisation}

\section{Trade and FDI}

Trade has increased from $19 \%$ of world output in 1950 to $36 \%$ in 1997, due to falling tariffs, rising real incomes, and consumer pull. Sea transport cost is down by $70 \%$ in real terms over 10-15 years, air by 3-4\% a year. FDI has risen even faster than trade, its share of world income going from $3.5 \%$ in 1973 to nearly $12 \%$ in 1997. Individual companies export in order to exploit successful innovations, sustain output, and reduce unit costs; FDI is sometimes driven by lower labour costs, but more often by market access considerations such as customer relationship, transport costs, brand control, and export barriers.

\section{Multinational Enterprises}

Sales by affiliates of non-local parents were $\$ 9.5$ trillion in $1997^{3}, 1.8$ times world goods exports; in the US and Japan exports to affiliates are about $30 \%$ of all exports. Important aspects for a medium-sized open economy like the UK are : whether the MNE produces the same product in many countries, or splits up the production chain between countries; what role MNEs play (and this is the subject of some debate ${ }^{4}$ ) as creators and exploiters of knowledge capital; and the degree of autonomy afforded to local management. These features

\footnotetext{
${ }^{3}$ UNCTAD estimate

${ }^{4}$ Living on Thin Air, Charles Leadbeater (Viking, 1999) p.102-103
} 
and how they develop affects both the attractiveness of the UK as an operational site, and the levers available to UK government to regulate MNE activities.

\section{Mega-Mergers}

Are mergers (especially of MNEs) achieving new scale and reach, and if so what are the implications for government and regulators? It seems that merger activity correlates with stock-market swings; that the main beneficiaries are usually the shareholders of the firm taken over; that mergers have little effect on efficiency ${ }^{5}$; and that there is no general association between firm size and innovation ${ }^{6}$. Size as a route to speed and reach, and profit impact of global market share, may be forces driving mega-mergers, but the resultant behemoths must then achieve agility at scale. Such strategies if successful allow MNEs to maximise the competitiveness of their corporate systems as a whole ${ }^{7}$. New organisational forms ${ }^{8}$ and business models are required, and widespread success will have implications for national industrial structures ${ }^{9}$.

\section{Industry Location}

Will firm location become more concentrated or more dispersed? There are arguments both ways, but recent experience shows increasing clustering particularly for knowledge industries. This may lead to a core of prosperity and a periphery of relative poverty, with rising income inequality and consequent social and political implications.

\section{Society, Ethics, Politics, and Sustainability}

As well as economic and commercial globalisation, Anthony Giddens ${ }^{10}$ and others ${ }^{11}$ have drawn attention to social, environmental, cultural, and political, globalisations. They are interrelated in ways we do not yet understand, still less control. Much of the literature ${ }^{12}$ to

\footnotetext{
${ }^{5}$ Note by Siobhan Pointer of DTI CP2, 20 Apr 1999

6 Innovation, firm size and market structure: Schumpeterian hypotheses and some new themes, George Symeonidis (OECD Economics Working Paper 161, 1996 - OCDE/GD(96)58). He notes that there may be an association between size and innovation in some circumstances.

7 World Investment Report 1998 (UNCTAD, 1999)

${ }^{8}$ See, for instance, Patching : Restitching Business Portfolios in Dynamic Markets, Kathleen Eisenhardt and Shona Brown (Harvard Business Review, May-June 1999)

In the Hurricane's Eye, Raymond Vernon (Harvard University Press, 1998)

${ }^{10}$ BBC Reith Lectures on Globalisation, 1999

${ }^{11}$ For a popular (but highly polemic) approach, see The Lexus and the Olive Tree, Thomas Friedman (Harper Collins, 1999); or for a more academic analysis, Globalisation and Sites of Conflict: Towards Definition and Taxonomy, Richard Higgott and Simon Reich (ESRC Centre for Globalisation \& Regionalisation Working Paper No. 01/98, March 1998). Globalisation, Malcolm Waters (Routledge, 1995), Global Shift, Peter Dicken (Paul Chapman, 1998), and Global Transformations, David Held et al (Polity Press, 1999) are rare multidisciplinary texts.

12 This is vast, varied, frequently polemic, and often not aligned with conventional groupings. Mastering Global Business (FT Pitman, 1998) is a good survey from a business view. Civilization and Capitalism $15^{\text {th }}-18^{\text {th }}$ Century, Fernand Braudel
} 
date tends to concentrate on one or another aspect alone, and thus misses interactions between them. For example, a link between migration and innovation appears to be one element in the success of "Silicon Valley". will interact with personal value systems, are probably the single largest imponderable for governments and businesses (especially MNEs) over the next 20 years ${ }^{14}$. For instance, many believe that natural resources are being used too fast and "should" have higher values. Such values would materially change the pattern of world trade and distribution of income, notably as between developed and developing countries. Building on such beliefs, NGOs such as Greenpeace can turn issues such as "care for the environment" into global brands and exploit their emotive force world-wide, usually to exert pressure on governments and multilateral NGOs. Governments may not be in control here - NGOs can increasingly set the pace on such issues, in particular regarding MNE activity.

\section{Examples of Impact on DTI}

\section{The Weightless Economy?}

Knowledge-based industries are often seen as global, but their physical manifestations tend to remain obstinately grounded. Saskia Sassen has looked at the links between financial systems and their supporting services which tie them to specific places like the City of London ${ }^{15}$. Michael Porter has shown how the interaction of competition and co-operation give rise to clustering of related enterprises ${ }^{16}$. Both draw attention to the way in which some elements and actors become weightless and global, while others remain dependent on location or proximity. In such work we can glimpse how globalisation changes the nature of both business and the societies in which it is transacted, and how technology changes the

\footnotetext{
(California UP, 3 vols.) provides a pre-industrial backdrop. Other views are to be found in The Information Age : Economy, Society, and Culture, Manuel Castells (Blackwell, 3 vols., 1996, 1997, 1998); The End of the Nation-State, Kenichi Ohmae (Harper-Collins, 1996); Has Globalization Gone Too Far, Dani Roderick (Brookings Institution, 1997); The Future and Its Enemies, Virginia Postrel (Free Press, 1998); The Clash of Civilizations : The Debate, Samuel Huntingdon et al (Foreign Affairs, 1996); Is Global Capitalism Working? (Foreign Affairs, 1998); Globalization - The Human Consequences, Zygmunt Bauman (Polity Press, 1998); A Vision for the World Economy - Openness, Cohesion, and Diversity, Robert Z Lawrence et al (Brookings Institution, 1996); Global Public Policy - Governing without Government?, Wolfgang Reinicke (Brookings Institution, 1998); Globaphobia - Confronting Fears about Open Trade, Gary Burtless et al (Brookings Institution, 1998); Global Dreams - Imperial Corporations and the New World Order, Richard Barnet and John Kavanagh (Simon \& Schuster, 1994); Information Rules, Carl Shapiro and Hal Varian (Harvard, 1999); Which World?, Allen Hammond (Earthscan, 1998); The Retreat of the State, Susan Strange (Cambridge UP, 1996)

${ }^{13}$ Charles Leadbeater, op. cit., p141. Also see GenEquity - A Year in the Life of the Digital Goldrush, Po Bronsen (Wired, July 1999, p113)

14 When Good Companies do Bad Things - Risk and Responsibility in an Age of Globalization, Peter Schwarz and Blair Gibb (Wiley, 1999)

${ }_{15}$ Global Financial Centres, Saskia Sassen (Foreign Affairs 98(1), Jan/Feb 1999)

${ }^{16}$ On Competition, Michael Porter (Harvard University Press, 1998)
} 
relationship between global and local. This complex relationship between the local and the global, particularly with regard to issues such as income distribution and skills development, bears directly on the UK's objective to be "the best environment for e-commerce in the world".

\section{Company Competitiveness}

On one view, restrictions imposed by global competitive pressures limit government's ability to pursue social and economic policies which detract from competitiveness. An alternative view might see the political necessity of pursuing such policies as a cause of limits to competitiveness, engendering economic weakness. More generally, what are the implications of globalisation for the ability of the UK (or the EU) to act freely? Do new global spaces make such action partially or completely untenable?

\section{Global Cities}

Saskia Sassen describes how major urban centres tend to become more connected to each other than to their local economies ${ }^{17}$. At the same time, they are subject to claims from their populations of low-income "others". This clash between the "urban glamour zone" and the "urban war zone" causes many problems, not least that of creating appropriate regulatory and public service regimes. Does DTI need to understand or help resolve these conflicting claims?

\section{Reach of the Nation-State in Infospace}

One effect of technology has been to circumscribe the reach of nation-states - particularly their ability to control information, the currency of the knowledge economy. As in the "space of cities" the internet has created new spaces with varied and competing claims on them. The voice of the nation-state is one amongst many, and often not the loudest. For example, in the music industry individuals are undermining information property rights by internet distribution of the works of others. Suppose that the existing regulatory structure - copyright - is unsustainable here. DTI's role is to be the promoter of a favourable business environment: how should it act? For example, should it support copyright owners, or those who propose radical new business models?

\footnotetext{
${ }^{17}$ Globalisation and its Discontents, Saskia Sassen (The New Press, 1998)
} 


\section{Global Finance and Other Global Systems}

In finance the mindset is not "going global" - a cultural and attitudinal shift to "already global" has occurred ${ }^{18}$. Money is moved around the financial system without thought to national boundaries, and exposure to the markets is now both the risk and the signal of firstrank statehood. Intellectual capital is going the same way, with a developing global market in expertise and knowledge. Only "plant" remains stubbornly located, and in many industries its useful life is much shorter than it used to be. If companies are prepared to abandon even "plant", what criteria should be used to evaluate FDI cases? What levers are available to governments, and are they adequate? Explanations of particular events vary widely : how can better understanding and models be created?

\section{The Societal and Structural Underpinnings of Globalisation}

A recent EU report ${ }^{19}$ relates European under-performance in the globalising knowledge industries to such as insufficiently developed risk-taking, lack of a services mentality, uncoordinated research, inefficient IPR trading systems, and a defensive attitude to partnerships. These have economic consequences, but are not themselves primarily economic issues. Here the issue is not the international economic framework which permits enterprises to become global players, but what drives or inhibits individual enterprises in actually doing so. What more can DTI do to help UK businesses be global players?

\section{Global Firms and DTI's Organisation}

DTI's existing organisation tends to separate issues of supply, demand, and institutional framework (Figure 1), and thus to consider separately those aspects of globalisation which touch on each.

\footnotetext{
${ }^{18}$ Market Unbound - Unleashing Global Capitalism, Lowell Bryan and Diana Farrell (Wiley, 1996)

19 The Competitiveness of European Enterprises in the face of Globalisation - How it can be encouraged, EU Commission (Commission paper COM(98) 718, 1999)
} 


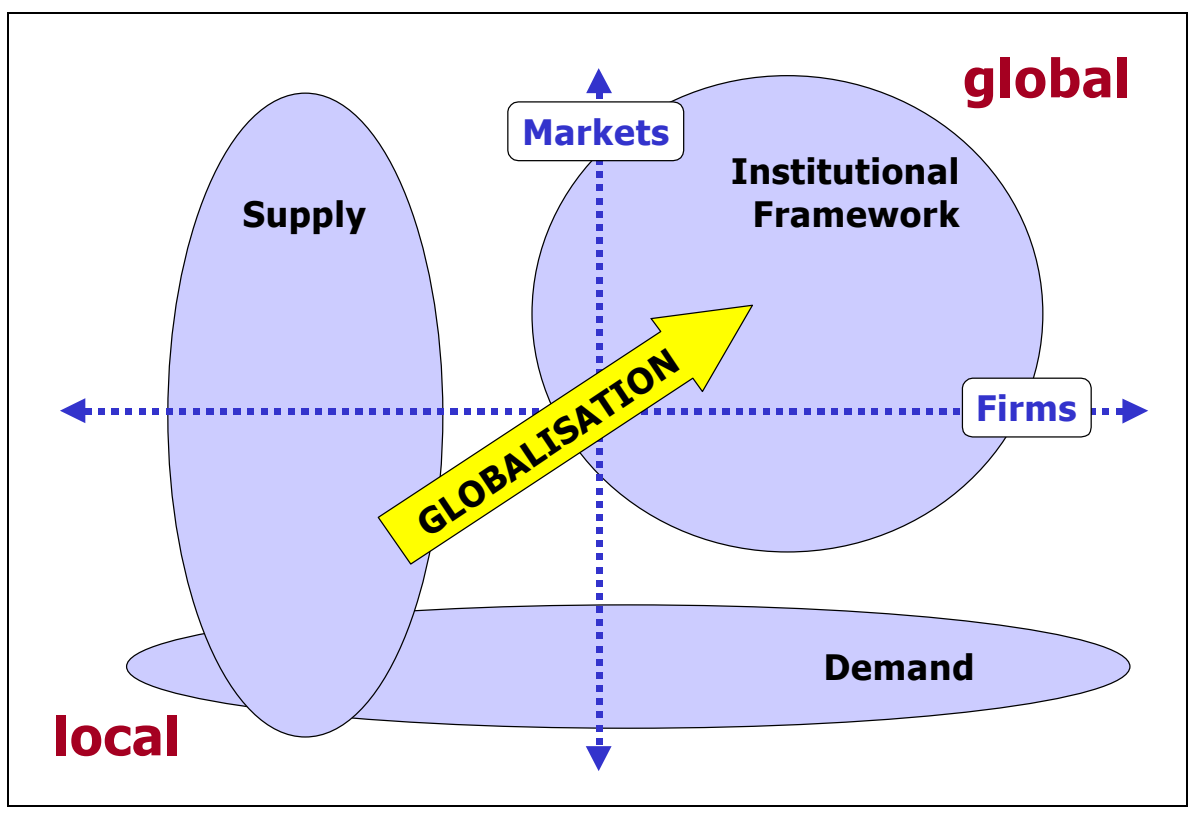

Figure 1 : DTI organisation relative to global markets and firms

Globalisation is dragging supply \& demand over into the institutional framework area, increasing the overlap and speed of interaction between the areas. New supply and demand features can appear rapidly and sometimes fit neither this framework nor existing industrial accommodations and norms. This may either slow technology deployment (e.g., DVD), or lead to battles between competing business models (e.g., MP3).

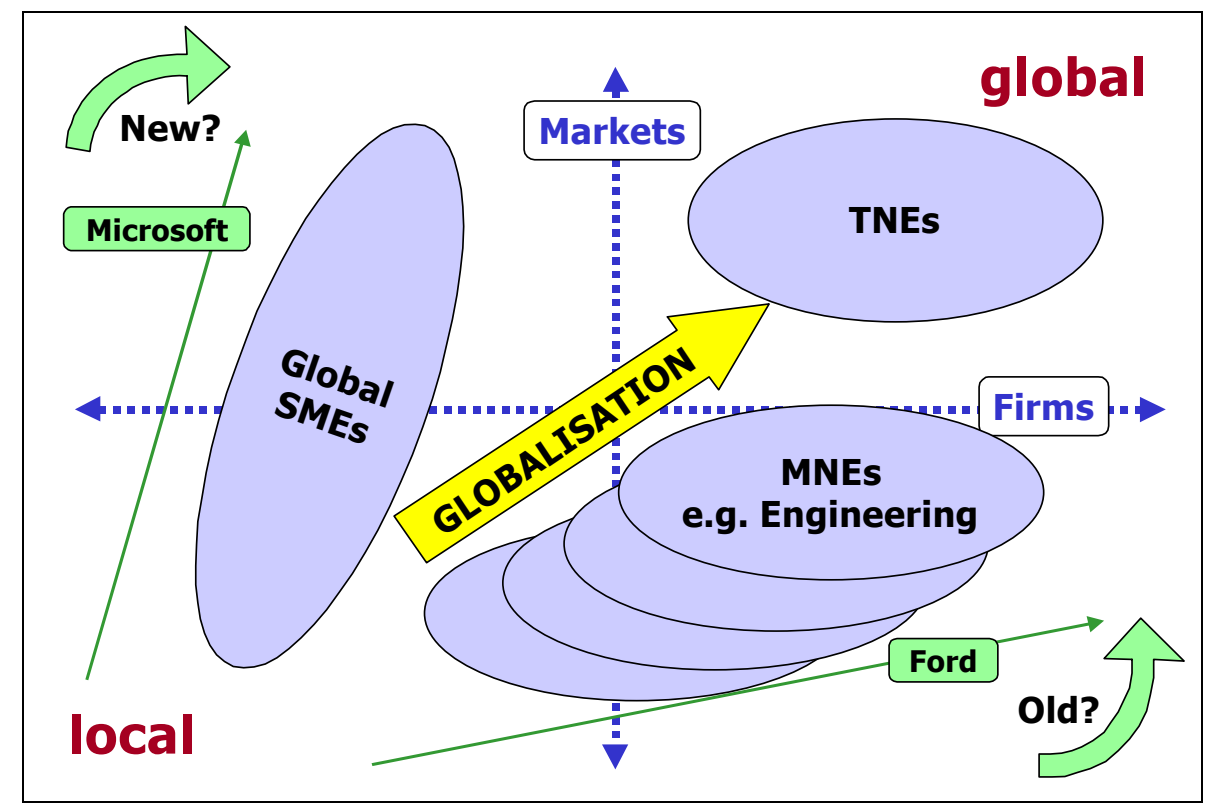

Figure $2:$ Routes to the global firm 
Within this framework, one can discern two routes from local enterprise to trans-national firm (Figure 2). The first is an "old" one where industrial concerns would become multinational by setting up national or regional subsidiaries. These operated as independent "silos", only slowly and recently beginning the transition to "global systems integrators". The second, enabled by the weightless nature of information goods, creates "global SMEs", which can move to operate globally whilst retaining their centre of gravity (and staff) in a single location - Microsoft being the most prominent example. Whichever route is followed, any firm which can retain agility whilst moving to the upper right quadrant will challenge the ability of government to keep up as well as that of other players to compete.

\section{So What for DTI?}

Multi-faceted, rapidly changing globalisation will profoundly affect the way corporations and other institutions operate. These changes will challenge the existing ways of government, extending into and beyond all areas of DTI's work.

For regulators, the increased mobility, agility, and variety of factors and actors make regulation harder, and mean talking to more people earlier and more often. In acting to improve business performance, it will be become progressively harder to identify potentially successful interventions. In both areas, unless the knowledge efficiency of the policy process can be improved, sheer logistics may dictate less action.

Within government, rapid co-ordination mechanisms are task-specific; general-purpose ones are slower, particularly on contentious issues. This makes proper balance difficult to achieve quickly, and makes it hard to keep up with innovation in business. Globalisation itself may make "joined up Government" more difficult.

The need to consider globalisation "in the round" thus exacerbates tension between policy coherence and good understanding of the specifics. Academia suffers the same type of difficulty $^{20}$. OECD work ${ }^{21}$ on globalisation has suggested as a remedy improved co-

\footnotetext{
${ }^{20}$ What Theory? The Theory in Mad Money, Susan Strange (ESRC Centre for Globalisation \& Regionalisation Working Paper No. 18/98, December 1998)

${ }^{21}$ Globalisation : What Challenges and opportunities for Governments?, Sally Washington (OECD, 1995)
} 
ordination between foreign ministries and other agencies. Setting up new "units" - singlepurpose co-ordination containers - has some advantages and is advocated by OECD, but it does not build fundamentally new organisational architecture. Government more than other actors has power to shape the future by arranging itself to deal with a range of possible futures; but incremental changes to structures designed for an earlier age may not achieve this.

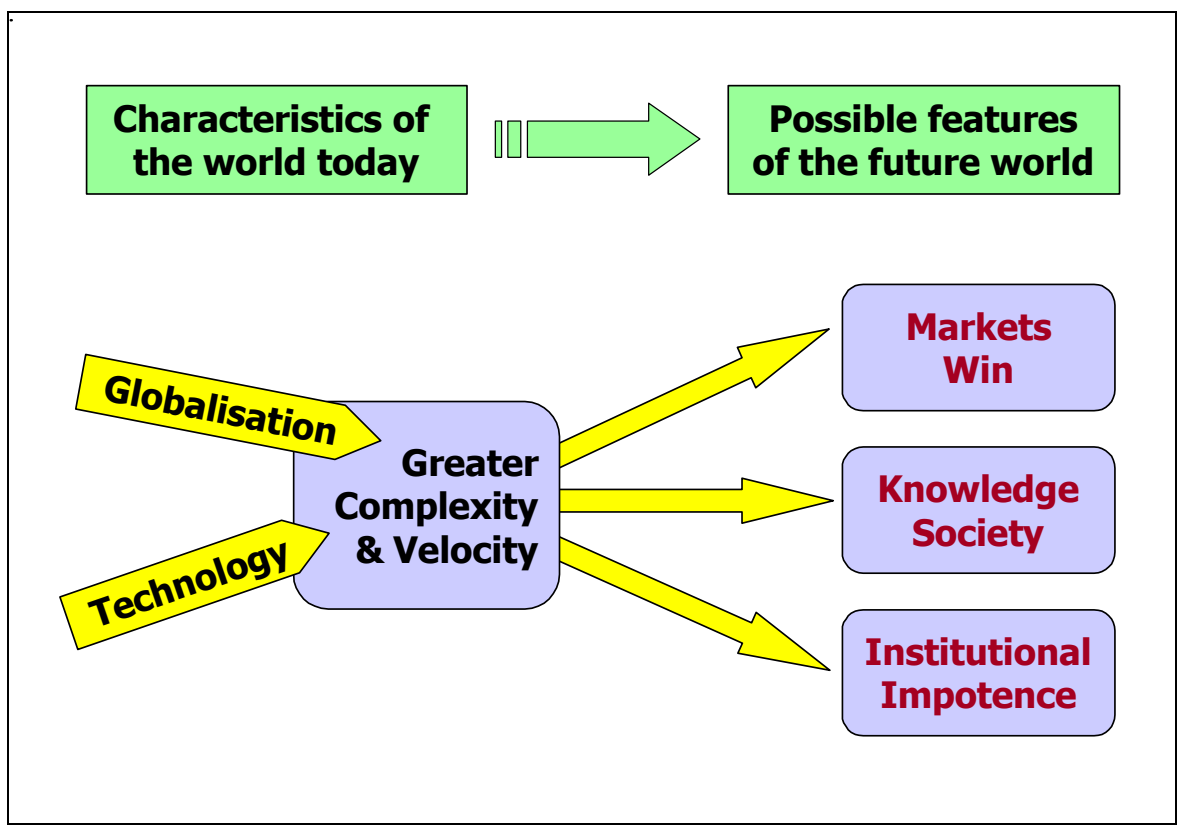

Figure 3 : Some scenarios for DTI

What are the possibilities? Figure 3 outlines three, drawing on the scenario work of the Chatham House Forum and others. One caveat is in order : the intent of these vignettes is to be provocative regarding the future role of government, rather than provide fully worked-out pictures of possible futures ${ }^{22}$, and readers wishing to go further are therefore urged to consult the original material ${ }^{23}$. In particular, they are designed to point up the co-evolution of governmental institutions with the environment in which they operate, and the possibility of steering that process better by thinking about different possible futures.

\footnotetext{
${ }^{22}$ Another Future Unit project, DTI2015, will produce more fully worked-out scenarios and test the reaction of policy-makers to them.

${ }_{23}$ Open Horizons : Three Scenarios for 2020 (Chatham House Forum, 1998); The Engines of Change (Chatham House Forum, 2000); Scenarios Europe 2010 : Five Possible Futures for Europe, Gilles Bertrand et al (EU Forward Studies Unit,
} 
In Markets Win, market growth is sufficient to avoid the worst effects of social exclusion, though income inequalities continue to rise. There is no mechanism other than the market to balance claims. Government fails to develop a knowledge-efficient policy process capable of keeping up with global business and is forced into retreat. Because of this, the Civil Service becomes progressively unable to attract "the brightest and the best". In this world, DTI is much smaller and is operating at the margins, unable to pull policy levers effectively because business (and, perhaps, NGOs) know better than it does what effect they will have and can continually second-guess it.

The government of Knowledge Society knows what its policy levers will do and is able to operate them wisely. It is fully "joined up", though not technocratic, with powerful institutions restraining market velocity where appropriate. It intervenes primarily through governance of the market or other "invisible hand" mechanisms ${ }^{24}$ rather than directly. To do this the forms of government have been radically reengineered, perhaps around individual project teams staffed by skilled specialists and supported by a central knowledge base. Many former departments no longer exist as such, though their functions can be faintly discerned in collections of projects and in the specialist teams who maintain the government's knowledge assets.

Institutional Impotence has governmental institutions much like the present ones, but the long boom has fizzled, with low growth and a large alienated underclass. The resulting political climate has placed government in thrall to nationalists, protectionists, and NGOs. The UK is engaged in continual low-intensity trade wars both inside and outside Europe, and soft security threats mass on the borders of the EU. Scotland is threatening to break away, seeing its future with the Nordic countries rather than the UK. DTI however is larger, because the complex tariffs and other protective mechanisms which it devises and operates are seen as an important part of a revived English national identity, "protecting our jobs".

1999); Policy Drivers for a Long Boom, DeAnne Julius (in The Future of the Global Economy : Towards a Long Boom?, OECD, 1999);

${ }^{24}$ See for instance Power \& Prosperity : Outgrowing Communist and Capitalist Dictatorships, Mancur Olson (Basic Books, 2000) 
A recent EU carrefour ${ }^{25}$ suggested there was much to learn from business; certainly, where government interacts with business, increasing speed of change points up the tension as never before. When other actors adopt new global ways to organise, co-ordinate, and achieve agility at scale, what should be the response of government?

${ }^{25}$ Globalisation and its Consequences - New Ways to Achieve Global Governance, EU Forward Studies Unit (EU, 1998) 